From the National Veterinary Laboratory, Ringsted, and the Statistical Research Unit, University of Copenhagen, Denmark.

\title{
Variations in Measures of Udder Health within a Short Period of Time
}

\section{The dynamic characteristics in diagnostics of subclinical mastitis based on cytological and bacteriological parameters}

\author{
By Niels Einar Jensen and Kim Knudsen
}

\begin{abstract}
Jensen, N. E. and K. Knudsen: Variations in measures of udder health within a short period of time. I. The dynamic characteristics in diagnostics of subclinical mastitis based on cytological and bacteriological parameters. Acta vet. scand. 1988, 29, 421-430. - Foremilk quarter samples were collected at morning and evening milkings on 6 dates during a 9 day period. At the end of the period teat puncture samples were drawn. Mastitis diagnoses based on bacteriological and cytological examinations were established for all 13 sets of samples from 45 cows (180 quarters). The effect of a fixed cell count (SCC) treshold value on mastitis diagnoses was studied as was the effect of variations in bacteriological state. The majority of shifts in diagnoses occurred only at few quarters due to the fact, that variation in the SCC-based diagnoses almost inevitably occurred in quarters with a SCC level close to the threshold. The future bacteriological state depended on both the previous and present bacteriological states in such a way, that changes in the future state seldom occurred when both the previous and present bacteriological states were the same. In conclusion, the quarter health state appeared to be fairly stable during a short period of time and the probability of changing mastitis diagnosis depended not only on the present diagnosis, but also on the actual somatic cell count and the previous bacteriological state.
\end{abstract}

quarter samples; milk; cattle; inflammation.

\section{Introduction}

Mastitis is defined as an inflammation of the mammary gland (Anon. 1987). The diagnosis is based on the pathological changes caused by the disease. The clinical form of mastitis does not offer any diagnostic problem. The situation is different when diagnosing the subclinical manifestation of the disease. This diagnosis must be based on examination of quarter milk samples, and changes in milk composition are the signs of inflammation. As pointed out by Klastrup (1985), the inflammatory changes may vary from insignificant deviation of the milk composition to complete cessation of the milk secretion.
The diagnosis of subclinical mastitis should also consider the dynamic nature of the disease as well as changes in milk composition caused by physiological processes.

In the practical situation the mastitis definition is not helpful since it does not indicate borderlines between the normal state and disease.

Diagnostic keys, employing fixed threshold values between the normal and pathological conditions, are easy to handle. They do not, however, take the above mentioned diagnostic, physiologic or dynamic problems into account.

The concentration of somatic cells (SC) is 
today the most commonly used inflammatory marker. Until the recent revision, the IDF (International Dairy Federation) recommended a threshold value of $500.000 \mathrm{SC} / \mathrm{ml}$ (Anon. 1971). In the Scandinavian countries the separating value was established at the level of $300.000 \mathrm{SC} / \mathrm{ml}$ (Klastrup \& Madsen 1974).

Neave (1975) and later Griffin et al. (1987) found a SCC threshold unnessary when diagnosing infectious subclinical mastitis caused by major pathogens.

The use of fixed threshold values is now not advised for any kind of mastitis work (Anon. 1987), and the diagnosis of other forms of subclinical mastitis than infectious is now more or less open for subjective consideration. The IDF recommendations are, however, not regarded as standards, but as guidelines.

Planning a larger experiment, aiming at elucidating the diagnostic value of some indirect inflammatory markers, it was found appropriate initially to study the variation of selected markers within a short period of time in a material originating from one herd. The present paper took inspiration from the report by Giesecke et al. (1985). These authors claimed that bovine udder health, determined by the now outdated IDF recommendations, could be regarded as extremely labile. Fixed SCC thresholds have been and are still to some extent used in various kinds of mastitis work. Therefore, it was considered reasonable to exploit the existing material to evaluate the stability/variability of udder helath states, determined by the Scandinavian diagnostic key, relate the results of those of Giesecke et al. (1985), and to search for possible causes of diagnostic shifts.

\section{Materials and methods}

A herd of 68 milking cows of the Red Da- nish Breed was available for the study carried out during the period June 5-14, 1985. The herd was loose housed and milked twice daily in a milking parlour $(2 \times 6)$. The technical performance of the milking equipment fulfilled the Scandinavian recommendations (Anon. 1978). Teat dipping was done at each milking with an iodophor in recommended concentration prior to and during the study period.

According to standard procedures (Anon. 1983), similar to those prescribed by the IDF (1981), foremilk samples from all cows were collected aseptically at morning (6 am) and evening ( $3 \mathrm{pm})$ milkings on the following dates: June $5,6,7,10,11$, and 12 . The total milk yield of all 68 cows was recorded once on June 8.

All 68 cows were slaughtered (June 13 and 14), and immediately after removal of the udder the teat skin was carefully cleaned and disinfected. From all lactating quarters teat puncture samples were drawn into sterile vacuum containers.

Thus, the complete material comprises 6 sets of morning foremilk, 6 sets of evening foremilk, and 1 set of teat puncture (cisterne) samples from each of the 68 cows.

Bacteriological examination of the milk samples and identification of mastitis pathogens were performed by standard laboratory methods (Anon. 1983) basically identical with the methods prescribed by the IDF (1981). However, only $0.03 \mathrm{ml}$ of milk was spread over half a plate. Somatic cells were counted electronically (Fossomatic).

Twentythree of the 68 cows were excluded from the calculations due to one or more of the following reasons: total milk yield less than $10 \mathrm{~kg} / \mathrm{d}$ (13 cows), 1 or more inactive (blind) quarters ( 9 cows), several missing values ( 2 cows), and intercurrent disease (1 cow). Thus, the calculations were based on data from 45 cows (180 quarters). Twenty- 
three of these cows were in their first lactation, 13 in their second, and 9 had 3 or more lactations.

Mastitis diagnoses were established for fore- milk quarter samples according to the Scandinavian recommendations (Klastrup \& Madsen 1974). This diagnostic key reveals the following quarter health conditions:

\begin{tabular}{lll}
\hline & \multicolumn{2}{c}{ Pathogenic bacteria } \\
\cline { 2 - 3 } Somatic cell count & \multicolumn{1}{c}{ absent } & \multicolumn{1}{c}{ present } \\
\hline SCC $<300,000 / \mathrm{ml}$ & normal (N) & presence of bacteria (PB) \\
SCC $>300,000 / \mathrm{ml}$ & aseptic mastitis (AM) & infectious mastitis (IM) \\
\hline
\end{tabular}

The stability of these conditions was evaluated by comparing the diagnosis of a quarter with the diagnosis of the same quarter $24 \mathrm{~h}$ later, i.e. the diagnosis established on examination of a morning sample was compared to the diagnosis of the following morning sample, and of an evening sample to the diagnosis of the following evening sample, with the exception of the $72 \mathrm{~h}$ between milkings on June 7 and June 10.

\section{Results}

The prevalence rates of the different quarter health conditions by sampling time are shown in Table 1.

On the average $16.2 \%$ of the quarters had the diagnosis IM, $6.5 \%$ AM, $12,9 \% \mathrm{~PB}$, and $64.1 \%$ were classified as $\mathrm{N}$. The number of the different diagnoses varied with the time of sampling. The general pattern was that at evening milkings more quarters were dia-

Table 1. Prevalence of mastitis diagnoses by sampling time. SCC threshold value: $300,000 / \mathrm{ml} .45$ cows.

\begin{tabular}{lccccc}
\hline & \multicolumn{5}{c}{ Diagnoses } \\
\cline { 2 - 5 } $\begin{array}{lcccc}\text { Sampling } \\
\text { time }\end{array}$ & $\begin{array}{c}\text { Infectious } \\
\text { mastitis (IM) }\end{array}$ & $\begin{array}{c}\text { Aseptic } \\
\text { mastitis (AM) }\end{array}$ & $\begin{array}{c}\text { Presence of } \\
\text { bacteria (PB) }\end{array}$ & $\begin{array}{c}\text { Normal } \\
\text { (N) }\end{array}$ & $\begin{array}{c}\text { Number of } \\
\text { quarters }\end{array}$ \\
\hline June 5 M* & 27 & 13 & 24 & 116 & 180 \\
June 5 E** & 30 & 11 & 15 & 123 & 179 \\
June 6 M & 31 & 11 & 20 & 117 & 179 \\
June 6 E & 26 & 19 & 18 & 116 & 179 \\
June 7 M & 27 & 10 & 25 & 117 & 179 \\
June 7 E & 30 & 13 & 24 & 112 & 179 \\
June 10 M & 29 & 11 & 31 & 109 & 180 \\
June 10 E & 34 & 14 & 27 & 105 & 180 \\
June 11 M & 29 & 7 & 30 & 113 & 179 \\
June 11 E & 33 & 13 & 15 & 119 & 180 \\
June 12 M & 23 & 9 & 29 & 119 & 180 \\
June 12 E & 30 & 10 & 21 & 119 & 180 \\
\hline Mean & 29.08 & 11.75 & 23.25 & 115.42 & \\
Range & $23-34$ & $7-19$ & $15-31$ & $105-123$ & \\
\hline
\end{tabular}

* Morning.

** Evening. 


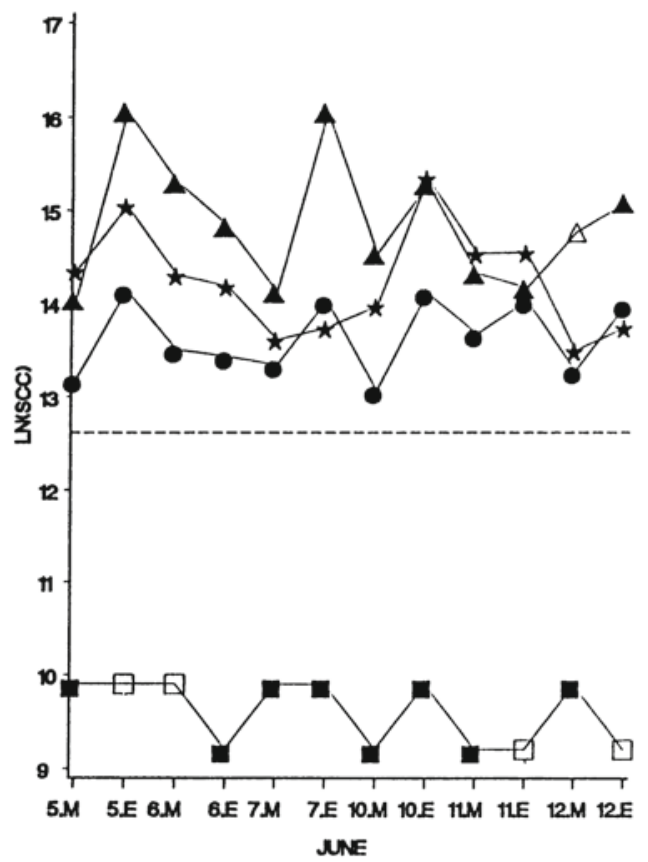

Figure 1. Bacteriological and cytological state at 6 morning and evening milkings for cow no. 291. Symbols: —- somatic cell count threshold $=$ $300,000 \mathrm{SC} / \mathrm{ml}$. $\mathrm{LN}(\mathrm{SCC})=$ natural logarithm of somatic cell count. $\square \square$ : right front quarter, $\mathrm{O}$ : left front quarter, $\Delta \boldsymbol{\Delta}$ : right rear quarter, $\star \star$ : left rear quarter.

Solid symbol: bacteriological positive.

Empty symbol: bacteriological negative.

gnosed as IM and AM than at morning milkings due to the fact that the SCC values were on the whole higher at the evening milkings.

The variation in SCC values - as well as the bacteriological state - are shown for 5 cows in Figures 1 to 5.

To eliminate the effect of the differences between morning and evening milkings and the uneven span due to the weekend June 8 and 9 , only four $24 \mathrm{~h}$ transitions per quarter were studied in each of the 6 sets of morning and evening samples. We here assume that the probability of changing mastitis diagno-

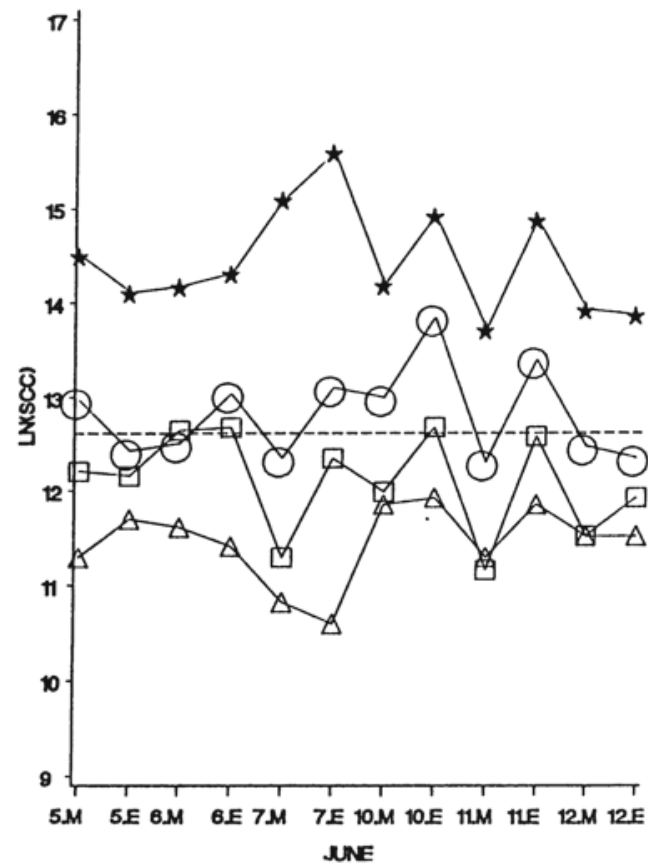

Figure 2. Bacteriological and cytological state at 6 morning and evening milkings for cow no. 364 . Symbols: see Fig. 1.

sis over a $24 \mathrm{~h}$ period is independent of whether the diagnosis was based on morning or on evening milkings. The results of 8 transitions per quarter comprising a total of 1432 transitions are listed in Table 2.

In $1215(85 \%)$ cases the diagnoses were stable while the quarter health condition improved in 119 and deteriorated in 98 cases. Thus, changes were observed in 217 cases within $24 \mathrm{~h}$ periods. Table 2 also shows that $197(83 \%)$ of the 236 cases with an initial diagnosis IM retained this diagnosis, 16 (7\%) developed AM, 18 (8\%) PB, while 5 ( $2 \%$ ) changed to N. Minor fluctuations were 


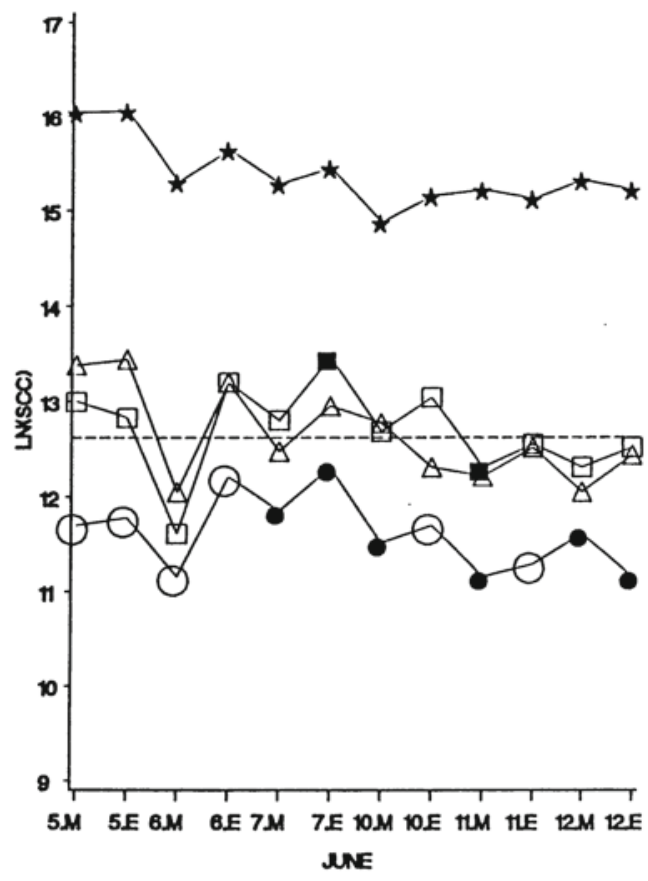

Figure 3. Bacteriological and cytological state at 6 morning and evening milkings for cow no. 368 . Symbols: see Fig. 1.

Table 2. Initial and final prevalence of quarters and number of diagnoses observed at $143224 \mathrm{~h}$ transitions. SCC threshold value: $300,000 / \mathrm{ml}$.

\begin{tabular}{|c|c|c|c|c|c|}
\hline \multirow{2}{*}{$\begin{array}{l}\text { From } \\
\text { diagnosis }\end{array}$} & \multicolumn{4}{|c|}{ To diagnosis } & \multirow{2}{*}{$\begin{array}{c}\text { Initial } \\
\text { prevalence }\end{array}$} \\
\hline & IM & AM & PB & $\mathrm{N}$ & \\
\hline IM & $\begin{array}{l}197 \\
83 \% \\
\end{array}$ & $\begin{array}{l}16 \\
7 \% \\
\end{array}$ & $\begin{array}{l}18 \\
8 \%\end{array}$ & $\begin{array}{l}5 \\
2 \% \\
\end{array}$ & $\begin{array}{l}236 \\
100 \%\end{array}$ \\
\hline $\mathrm{AM}$ & $\begin{array}{l}7 \\
7 \%\end{array}$ & $\begin{array}{l}64 \\
65 \%\end{array}$ & $\begin{array}{l}3 \\
3 \%\end{array}$ & $\begin{array}{l}25 \\
25 \%\end{array}$ & $\begin{array}{c}99 \\
100 \%\end{array}$ \\
\hline PB & $\begin{array}{l}21 \\
12 \%\end{array}$ & $\begin{array}{l}2 \\
1 \%\end{array}$ & $\begin{array}{l}105 \\
58 \%\end{array}$ & $\begin{array}{l}52 \\
29 \%\end{array}$ & $\begin{array}{l}180 \\
100 \%\end{array}$ \\
\hline $\mathbf{N}$ & $\begin{array}{l}2 \\
0 \%\end{array}$ & $\begin{array}{l}10 \\
1 \%\end{array}$ & $\begin{array}{l}56 \\
6 \%\end{array}$ & $\begin{array}{l}849 \\
93 \%\end{array}$ & $\begin{array}{l}917 \\
100 \%\end{array}$ \\
\hline
\end{tabular}

Final

\begin{tabular}{llllll} 
prevalence & 227 & 92 & 182 & 931 & 1432 \\
\hline
\end{tabular}

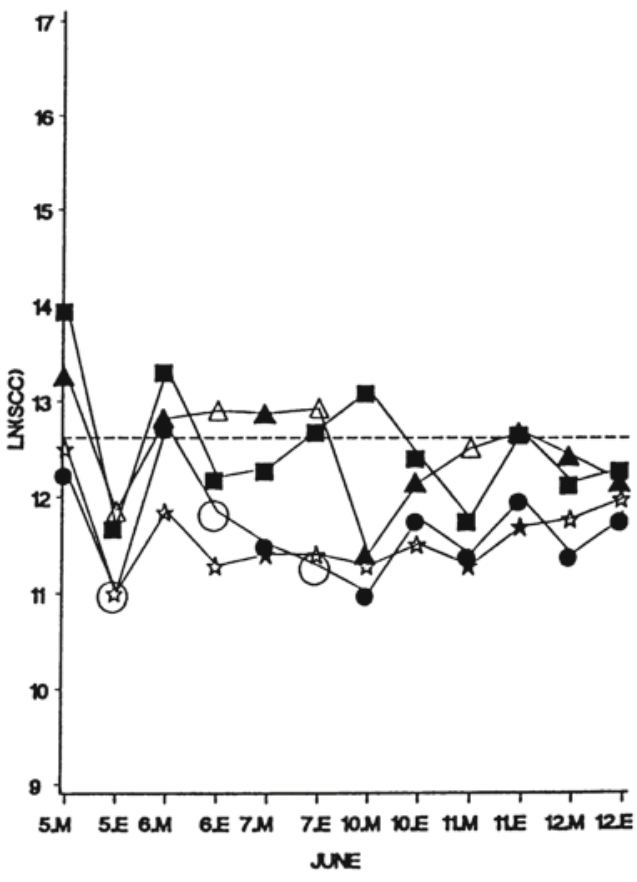

Figure 4. Bacteriological and cytological state at 6 morning and evening milkings for cow no. 425 . Symbols: see Fig. 1.

also seen in the group of the initially normal cases while a proportionally larger number of initially AM and PB cases shifted to other diagnoses.

A change in diagnosis may be caused either by a change in the SCC across the fixed threshold value or by a change in the bacteriological state. Table 3 lists the number of changes according to the threshold value of 300,000 SC.

Shifts were observed in $86(6 \%)$ cases.

In Table 4 both the higher and lower SCC groups were divided into 2 groups. Three SCC threshold values, namely 150,000 , 300,000 , and 450,000 were thereby considered.

It appears that the probability of a transition depended on the level of SCC. 


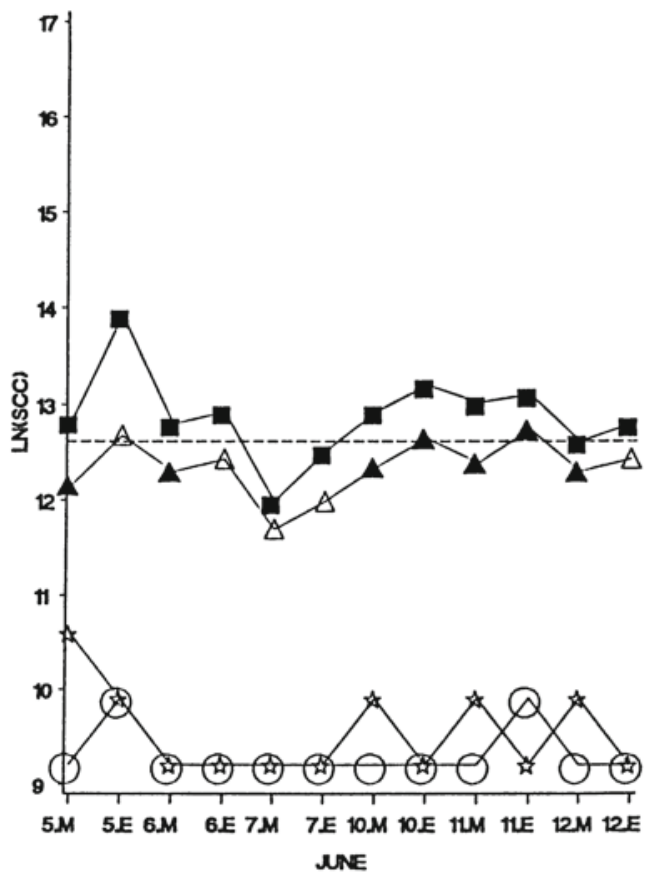

Figure 5. Bacteriological and cytological state at 6 morning and evening milkings for cow no. 579 . Symbols: see Fig. 1.

Table 3. Initial and final prevalences of quarters in two SCC classes and number of shifts observed at $143224 \mathrm{~h}$ transitions.

\begin{tabular}{lccc}
\hline & \multicolumn{2}{c}{ To class } & \\
\cline { 2 - 3 } $\begin{array}{l}\text { From } \\
\text { class }\end{array}$ & $\begin{array}{c}\mathrm{SCC} / \mathrm{ml} \\
>300,000\end{array}$ & $\begin{array}{c}\mathrm{sCC} / \mathrm{ml} \\
<300,000\end{array}$ & $\begin{array}{c}\text { Initial } \\
\text { prevalence }\end{array}$ \\
\hline $\mathrm{SCC} / \mathrm{ml}$ & 284 & 51 & 335 \\
$>300,000$ & $85 \%$ & $15 \%$ & $100 \%$ \\
\hline $\mathrm{SCC} / \mathrm{ml}$ & 35 & 1062 & 1097 \\
$\leq 300,000$ & $3 \%$ & $97 \%$ & $100 \%$ \\
\hline $\begin{array}{l}\text { Final } \\
\text { prevalence }\end{array}$ & 319 & 1113 & 1432 \\
\hline
\end{tabular}

Table 4. Initial and final prevalences of quarters in four SCC classes and number of shifts observed at $143224 \mathrm{~h}$ transitions.

\begin{tabular}{lccc}
\hline \multirow{2}{*}{$\begin{array}{l}\text { From } \\
\text { class }\end{array}$} & \multicolumn{2}{c}{ To class } & \\
\cline { 2 - 3 } & $\begin{array}{c}\mathrm{SCC} / \mathrm{ml} \\
>300,000\end{array}$ & $\begin{array}{c}\mathrm{SCC} / \mathrm{ml} \\
<300,000\end{array}$ & $\begin{array}{c}\text { Initial } \\
\text { prevalence }\end{array}$ \\
\hline \multirow{2}{*}{450,000} & 258 & 22 & 280 \\
$300,000-$ & $92 \%$ & $8 \%$ & $100 \%$ \\
450,000 & 26 & 29 & 55 \\
\hline $300,000-$ & 29 & $75 \%$ & $100 \%$ \\
150,000 & $28 \%$ & $72 \%$ & 104 \\
$<150,000$ & 6 & 987 & 993 \\
& $1 \%$ & $99 \%$ & $100 \%$ \\
\hline
\end{tabular}

Final

prevalence

319

1113

1432

Table 5. initial and final prevalences of bacteriological positive and negative cases and number of shifts observed at $143224 \mathrm{~h}$ transitions.

\begin{tabular}{lccc}
\hline & \multicolumn{2}{c}{ To } & \\
\cline { 2 - 3 } & $\begin{array}{c}\text { bacteriolo- } \\
\text { gical } \\
\text { positive }\end{array}$ & $\begin{array}{c}\text { bacteriolo- } \\
\text { gical } \\
\text { negative }\end{array}$ & $\begin{array}{c}\text { Initial } \\
\text { prevalence }\end{array}$ \\
\hline bacteriological & 341 & 75 & 416 \\
positive & $82 \%$ & $18 \%$ & $100 \%$ \\
\hline $\begin{array}{l}\text { bacteriological } \\
\text { negative }\end{array}$ & 68 & 948 & 1016 \\
\hline $\begin{array}{l}\text { Final } \\
\text { prevalence }\end{array}$ & 709 & $93 \%$ & $100 \%$ \\
\hline
\end{tabular}

Table 5 gives the number of shifts in diagnoses caused by a change in the bacteriological state.

It appears that, although the initial and final prevalences were almost identical, shifts were observed in 143 cases.

In Table 6 the material is rearranged not only taking the present but also the previous bacteriological state into account. 
Table 6. Number of shifts observed from previous bacteriological state positive and negative at $72024 \mathrm{~h}$ transitions.

a) Previous bacteriological state positive

\begin{tabular}{lcc} 
& \multicolumn{2}{c}{ To future } \\
\cline { 2 - 3 } $\begin{array}{l}\text { From } \\
\text { present }\end{array}$ & $\begin{array}{c}\text { bacteriological } \\
\text { positive }\end{array}$ & $\begin{array}{c}\text { bacteriological } \\
\text { negative }\end{array}$ \\
\hline bact. & 159 & 13 \\
positive & $92 \%$ & $8 \%$ \\
\hline bact. & 15 & 31 \\
negative & $33 \%$ & $67 \%$ \\
\hline
\end{tabular}

b) Previous bacteriological state negative

To future

\begin{tabular}{lcc} 
& \multicolumn{2}{c}{ To future } \\
\cline { 2 - 3 } $\begin{array}{l}\text { From } \\
\text { present }\end{array}$ & $\begin{array}{c}\text { bacteriological } \\
\text { positive }\end{array}$ & $\begin{array}{c}\text { bacteriological } \\
\text { negative }\end{array}$ \\
\hline bact. & 16 & 16 \\
positive & $50 \%$ & $50 \%$ \\
\hline bact. & 21 & 449 \\
negative & $4 \%$ & $96 \%$ \\
\hline
\end{tabular}

It is seen that if the bacteriological state was stable for two consecutive days, then the chance/risk of changing state was $8 \%$ or below. Hence, for the majority of transitions the bacteriological state was much more stable than Table 2 or Table 5 imply. If the present bacteriological state differed from the previous, the outcome of a third test could only confirm the present state in $67 \%$ and $50 \%$ of quarters with the present state negative and positive, respectively.

When focusing on the state of the individual quarters, rather than the number of transitions, the state of $144(80 \%)$ of the 180 quarters did not vary when the diagnoses were based on the SCC. The 86 shifts observed at the 1432 possible transitions concerned the remaining $36(20 \%)$ quarters.

Twentytwo of these showed 2 or less shifts. Only 14 quarters were responsible for the majority (53) of the shifts in the SCC diagnoses.

Turning to the bacteriology, 84 (46.7\%) quarters were constantly negative and 29 (16.1\%) constantly positive. The remaining $67(36.7 \%)$ displayed a varying bacteriological state. However, in most of these quarters (39) the bacteria were only found occassionally ( 1 to 3 times). Thirteen quarters had a relatively constant bacteriological state $(9$ to 11 of the 12 samples positive), and frequent bacteriological findings ( 4 to 8 of the 12 samples positive) were observed in only 15 quarters.

The pathogens which could be isolated from the 96 quarters from 1 or more of the 12 sets of quarter milk samples were (number of quarters and symbol for pathogen are given in brackets): Staph. aureus (50 S), Str. dysgalactiae (13 Y), coagulase negative staph. (20 M), coliforms (11 K), Corynebacterium pyogenes (1 P), and Str. uberis (1 U). However, only 40 quarters were bacteriologically positive when the teat puncture (cistern) samples were cultured $(17 \mathrm{~S}, 6 \mathrm{Y}, 12 \mathrm{M}, 4$ $\mathrm{K}, 1 \mathrm{P})$. Twentysix (65\%) of those were bacteriologically positive ( $15 \mathrm{~S}, 4 \mathrm{Y}, 4 \mathrm{M}, 3 \mathrm{~K})$ in all of the preceding 12 sets of quarter milk samples while 14 quarters $(2 \mathrm{~S}, 2 \mathrm{Y}, 8$ M, $1 \mathrm{~K}, 1 \mathrm{P}$ ) varied slightly. On an average 8 of the 12 sets were positive. Three cisterne negative quarters had a history of constant positive bacteriology $(2 \mathrm{~S}, 1 \mathrm{~K})$. In the vast majority (53) (31 S, $7 \mathrm{Y}, 8 \mathrm{M}, 6 \mathrm{~K}, 1 \mathrm{U}$ ) of the 56 cisterne negative quarters changes in the bacteriological state were observed. On an average only 3.3 of the 12 sets of preceding quarter milk samples were positive in this category.

\section{Discussion and conclusions}

In this study the "Scandinavian" SCC threshold value of $300,000 \mathrm{SC} / \mathrm{ml}$ was used. A preliminary analysis, using the IDF value of 
500,000 cells $/ \mathrm{ml}$ gave almost identical results. Using the IDF mastitis criteria in a study similar to the present, Giesecke et al. (1985) found that $79.53 \%$ of IM cases, $28.74 \%$ of AM, $66.1 \%$ of PB and $91.51 \%$ of $\mathrm{N}$ cases persisted throughout twentyone $24 \mathrm{~h}$ periods. These authors also calculated the "mean persistence of bacteriologically and otherwise diagnostically identical states of udder health". The "mean persistence" of the normal state $(\mathrm{N})$ was 5.96 days, the other health states shorter. Based on these findings they concluded that "bovine udder health may be regarded as extremely labile". The present investigation revealed that $83 \%$ of IM cases, $65 \%$ of AM, $58 \%$ of PB and $93 \%$ of $N$ cases persisted from sampling to sampling (Table 2). Thus, except for the case of AM, the figures are almost identical with those of Giesecke et al.

Shifts in the SCC based diagnoses were observed in 86 cases (Table 3 ) and in the bacteriological diagnoses in 143 cases (Table 5). Considering transitions, it should be remembered that a change in SCC level across the fixed borderline, either at the start or end of a study period or one irreversible change during the period results in one shift in diagnosis. A reversible change in SCC across the threshold value during the observation period will result in two shifts in diagnosis. Similarly, a change in bacteriological state during the study period results in registration of two shifts in diagnosis, but at the start and end in one shift only.

When one uses a transition matrix (seen in Table 2), as also done by Giesecke et al. (1985), it is usually assumed that changes in time have the same probability for all quarters in each of the 4 diagnostic classes, IM, AM, PB and N. Shifts in mastitis diagnoses, however, do not fulfil this assumption. Table 4 clearly indicates that variations in SCC based diagnoses almost inevitably oc- cur in quarters with "normal" SCC level close to the 300,000 SCC threshold value and rarely in quarters with other SCC levels. Within a short period of time, where the state of udder health is virtually stable, changes in diagnoses caused by crossing the SCC threshold are observed. The observation that a quarter changes diagnosis in this way does not necessarily imply an improvement or a deterioration in its condition of health, but may simply be due to the fact that the quarter's SCC value lies in the vicinity of the treshold value. However, the total number of shifts was low (86) and only 14 quarters were responsible for the majority (53) of shifts.

For a given bacteriological state, a change away from this state did not occur with equal probability for all quarters. The probability of shifts does not depend only on the present, but also on the previous bacteriological state. This is partly in accordance with Neave (1975) and Griffin et al. (1987). They hold the view that infectious subclinical mastitis diagnoses can safely be based on bacteriological examination of 2 successive samples. This examination showed, that if the present bacteriological state differed from the previous, a confirming third test was useful in only $67 \%$ and $50 \%$ of quarters with present state negative and positive, respectively. This situation concerned very few transitions (31) (Table 6) and only 15 quarters accounted for the majority of bacteriological variation.

Turning to the point of view of Giesecke et $a l$. it is evident, that the use of a transition matrix which only includes the present bacteriological state may be misleading. Also, the persistence of a mastitis diagnosis will clearly depend on the actual measured SCC value, whether the value is close to the threshold or not. Thus, calculating the mean value of persistence of a mastitis diagnosis of 
all quarters regardless of the actual SCC value does not seem appropriate either.

The relative stability of the "Scandinavian" mastitis diagnoses appear from the fact, that the 86 shifts observed in SCC based diagnoses could be referred to 36 of the 180 quarters, but only 14 quarters $(7.8 \%)$ were responsible for the majority $(53 / 86)$ of these shifts. Similarly, only 19 quarters displayed frequent bacteriological variations, changing bacteriological state 3 to 6 times of the 8 possible shifts and accounting for 75 of the total of 143 bacteriologically based shifts. If bacteria were cultured from cisterne puncture samples almost all preceding quarter milk samples were positive too. Infrequent positive bacteriological state in quarter milk samples was related to cisterne negative state.

Based on the results of the present study it must be maintained that, despite variations apparent for several quarters, few quarters showed frequent shifts. It seems necessary to study further the nature of the occassionally occurring bacteriological findings, their relation to high and low SCC classes and the number of colony forming units (CFU) recovered from such findings. The effect on the sensitivity and specificity of the bacteriological test is evident and this will be elucidated in a subsequent paper.

Additionally, it may be concluded that although a diagnostic key with a threshold value for SCC is simple and in our hands works well in field work, it gives an incomplete picture of the dynamic characteristics of subclinical mastitis. When utilizing a near continuous measure, such as SCC, a dichotomization will result in a loss of information. A more sophisticated approach would be to perform an analysis of variance with random effects. Components of variance, influencing the SCC level and the level of other inflammatory markers could then be determined. Statistical studies on the present and other materials are in progress.

\section{Acknowledgements}

The authors thank Mrs. B. Berg for excellent assistance. The project was supported by the Danish Agricultural and Veterinary Research Council, grant no. 5.33.44.00.

\section{References}

Anon: A monograph on bovine mastitis. International Dairy Federation 1971.

Anon: Nordic recommendations for milking plants, function, dimensions and installation. Danish Dairy Federation 1978.

Anon: Laboratory methods for use in mastitis work. International Dairy Federation 1981, Document 132.

Anon: Instructions for mastitis laboratories. Danish State Veterinary Service 1983.

Anon: Bovine mastitis. Definition and guidelines for diagnosis. International Dairy Federation 1987, Bulletin No. 211, 3-8.

Giesecke WH, Barnard ML, Mendelovish MG: Diagnostic and dynamic characteristics of various subclinical udder conditions monitored by means of the IDF criteria. Kieler milchwirtschaftliche Forschungsberichte 1985, 37, 354-359.

Griffin TK, Morant SV, Dodd FH: Diagnosing infectious subclinical mastitis in surveys or large scale experiments. The analysis and interpretation of the results of an international trial organised by the IDF mastitis expert group (A2). International Dairy Federation 1987, Bulletin No. 211, 9-24.

Klastrup $O$, Madsen PS: Nordic recommendations on examination of quarter milk samples. Nordisk Veterinær Medicin 1974, 26, 197204.

Klastrup $O$ : Bovine mastitis. Definition and guidelines for diagnosis. Kieler milchwirtschaftliche Forschungsberichte 1985, 37, 254-260.

Neave FK: Diagnosis of mastitis by bacteriological methods alone. Proceedings of Seminar on Mastitis Control. International Dairy Federation 1975, Bulletin Document 85, 19-36. 


\author{
Sammendrag \\ Korttidsvariation af yversundhedsstatus. \\ I. Dynamiske karakteristika ved subkliniske \\ mastitisdiagnoser baseret på cytologiske og \\ bakteriologiske parametre. \\ På 6 datoer i løbet af en 9 dages periode blev der \\ ved morgen- og aftenmalkning aseptisk udtaget \\ kirtelprøver og ved afslutningen af perioden cister- \\ nepunktur-prøver. Det endelige materiale omfat- \\ tede 13 sæt prøver fra 45 køer (180 kirtler). Masti- \\ tisdiagnoser blev baseret på resultater af bakterio- \\ logiske undersøgelser og på cellebestemmelse. \\ $300.000 \mathrm{celler} / \mathrm{ml}$ blev valgt som grænseværdien \\ mellem sund og syg. Diagnoseskift blev forårsaget
}

\begin{abstract}
af variation af celletallet omkring grænseværdien og af variation i bakteriologisk status. Effekten af variation $\mathrm{i}$ begge mastitisdiagnostiske parametre blev studeret. Flertallet af diagnoseskift vedrørte kun få kirtler. Variation i den celletalsbaserede diagnose indtraf især, men næsten uundgåeligt når en kirtels celletal var tæt ved den valgte grænseværdi. Resultatet af en bakteriologisk undersøgelse var afhængig af både den tidligere og den seneste bakteriologiske status. Bakteriologisk forårsagede diagnoseskift indtraf således sjældent, når status ved to forudgående undersøgelser var identiske. Kirtlernes sundhedsstatus var forholdsvis stabil i løbet af forsøgsperioden.
\end{abstract}

(Received February 26, 1988).

Reprints may be requested from: Niels Einar Jensen, National Veterinary Laboratory, 2, Hangøvej, DK-8200 Århus N, Denmark. 